\title{
Topological and Developmental Gradients of Calbindin Expression in the Chick's Inner Ear
}

\author{
Hakim Hiel, ${ }^{1}$ Dasakumar S. Navaratnam, ${ }^{2}$ John C. Oberholtzer, ${ }^{2}$ and Paul A. Fuchs ${ }^{1}$ \\ ${ }^{1}$ Center for Hearing and Balance, Department of Otolaryngology, Head and Neck Surgery, Johns Hopkins University \\ School of Medicine, Baltimore, MD 21205, USA \\ ${ }^{2}$ Department of Pathology and Laboratory Medicine, University of Pennsylvania School of Medicine, \\ Philadelphia, PA 19104, USA
}

Received: 16 August 2000; Accepted: 30 April 2001; Online publication: 1 August 2001

\begin{abstract}
Mobile intracellular calcium buffers play an important role in regulating calcium flux into mechanosensory hair cells and calbindin D-28k is expressed at high levels in the chick's basilar papilla. We have used RTPCR, in situ hybridization, and immunohistology to demonstrate that calbindin expression varies systematically according to hair cell position and developmental age. RT-PCR using microdissected quarters of the posthatch basilar papilla showed that mRNA levels were lowest in the (low frequency) apex and higher in basal quadrants. In situ hybridization revealed calbindin mRNA in posthatch hair cells and supporting cells, with more intense labeling of hair cells from basal (high frequency) positions. A similar topology was obtained with calbindin antibodies. Neither calbindin riboprobe nor calbindin antibody labeled cochlear neurons. In contrast, a subset of large vestibular neurons and their calyciform endings onto Type I vestibular hair cells were strongly labeled by the calbindin antibody, while vestibular hair cells were negative for calbindin immunoreactivity. Likewise, calbindin in situ hybridization was negative for vestibular hair cells but positive in a subset of larger vestibular neurons. Calbindin mRNA was detected in hair cells of the basal half of the papilla at embryonic day 10 (E10) and calbindin immunoreactivity was detected at E12. Hair cells in the apical half of the papilla had equivalent calbindin
\end{abstract}

Correspondence to: Hakim Hiel, Ph.D. • Center for Hearing and Balance $•$ Traylor Research Building, Room $521 \cdot$ Johns Hopkins University School of Medicine $•$ Baltimore, MD 21205. Telephone: (410) 955 3877; fax: (410) 614 4748; email: hhakim@bme.jhu.edu expression two days later. Immunoreactivity appeared in abneural supporting cells days later than in hair cells, and not until E20 in neurally located supporting cells. These results demonstrate that calbindin message and protein levels are greater in high-frequency hair cells. This "tonotopic" gradient may result from the stabilization of a basal-to-apical developmental gradient and could be related at least in part to calcium channel expression along this axis.

Keywords: cochlea, hair cells, vestibule, mechanotransduction, embryonic, calcium buffering

\section{INTRODUCTION}

The transduction and frequency discrimination of sound takes place in the tonotopically organized hair cell epithelium of the vertebrate inner ear. The chick basilar papilla (the avian equivalent of the mammalian Organ of Corti) contains 10,000 hair cells (Tilney and Tilney 1986) that encode sounds in the frequency range from approximately 100 to $5000 \mathrm{~Hz}$ (Chen et al. 1994; Gray and Rubel 1985). As in all vertebrates, the hair cells of the chick's basilar papilla are morphologically and physiologically specialized to respond selectively to sounds of different frequencies. The size and shape of the hair cell (Tanaka and Smith 1978; Hirokawa 1978a), its innervation (Firbas and Muller 1983; Fischer 1992; Ofsie and Cotanche 1996), and physiology (Fuchs et al. 1988; Fuchs and Evans 1990; Murrow 1994) all vary systematically along and across the cochlear epithelium.

Among these features is included a varying demand 
on the calcium buffering and sequestration ability of the hair cells. For example, the number of mechanosensitive stereocilia increases from approximately 50 per hair cell in the low-frequency cochlear apex to more than 300 per cell in the high-frequency cochlear base (Tilney and Saunders 1983). Since transduction channels are located at the tips of stereocilia (Hudspeth 1982), this implies that channel number also varies tonotopically. Indeed, a qualitatively similar gradient in bundle morphology (Hackney et al. 1993) correlates with an increase in the number of mechanosensitive transducer channels in the basilar papilla of the turtle (Ricci and Fettiplace 1997). Therefore, calcium influx through the open transduction channels poses an increasing buffering load as one moves toward the cochlear base.

In addition to calcium that enters the hair bundle, the number of voltage-gated calcium channels in the basolateral membrane of each hair cell also increases as one moves from cochlear apex to base (MartinezDunst et al. 1997) and from lower to higher tuning frequencies in hair cells of turtle (Art and Fettiplace 1987). Voltage-gated calcium influx places an additional demand on calcium buffering in the hair cell, and, indeed, computational models of electrical tuning require an increase in buffer levels as tuning frequency rises (Wu and Fettiplace 1996; Wu et al. 1996). Finally, the efferent inhibition of chick hair cells depends on the influx of calcium for activation of calcium-dependent potassium channels (Fuchs and Murrow 1992; Martin and Fuchs 1992; McNiven et al. 1996). It is essential that this calcium signal not spread to activate transmitter release simultaneously from the same cells. As in mammals, the efferent innervation of the chick's basilar papilla is tonotopic, with a higher density of innervation in the mid- and basal cochlea (Ofsie and Cotanche 1996; Zidanic and Fuchs 1996).

Previous work has shown that the calcium-buffering protein calbindin D-28k is highly expressed in the chick's basilar papilla (Oberholtzer et al. 1988). We examined its distribution in serial cross sections of mature cochlea using in situ hybridization and immunohistology as well as with semiquantitative reversetranscriptase polymerase chain reaction (RT-PCR) on microdissected quarters of the basilar papilla. These experiments confirm that calbindin is expressed in the highest levels in hair cells of the cochlear base, but more uniformly in abneurally located supporting cells overlying the basilar membrane. In situ hybridization and immunohistology were used to chart the appearance of calbindin during the last ten days of embryonic development. A basal-to-apical gradient in expression appeared at the earliest times. Also, the very first appearance of calbindin message was in the basal pole of the hair cell, near the presumptive location of synaptic contacts.

\section{MATERIALS AND METHODS}

\section{Tissue preparation}

Decalcified temporal bones from embryonic (E10E20) and posthatch (1-2-week-old) Leghorn chickens were cryosectioned and used for in situ hybridization and immunohistology experiments. To avoid damage to the end organs, only a single plane of section was used throughout the temporal bone so that the orientation of sections through the cochlear duct varied from orthogonal at the midpoint of the basilar papilla to variably tangential, especially at the apical and basal extremes. Ten to $16-\mu \mathrm{m}$-thick sections were layered on Superfrost slides (Fisher Scientific, Pittsburgh, PA, USA) and placed with desiccant at $-20^{\circ} \mathrm{C}$ for shortterm storage until use. Long-term storage was at $-80^{\circ} \mathrm{C}$. Hatchlings were raised from fertilized eggs and utilized according to a protocol approved by the Johns Hopkins Animal Care and Use Committee.

For in situ hybridization experiments, temporal bones were removed and immediately fixed with icecold $4 \%$ paraformaldehyde buffered with $0.1 \mathrm{M}$ monobasic sodium phosphate $(\mathrm{pH} \mathrm{7.4)}$ and postfixed in the same solution for $12-24 \mathrm{~h}$ at $4^{\circ} \mathrm{C}$. Excess bone and connective tissue were dissected away and the innerear specimens were decalcified for up to $72 \mathrm{~h}$ at $4^{\circ} \mathrm{C}$ in $5 \%$ EDTA containing $3 \%$ paraformaldehyde buffered with $0.1 \mathrm{M}$ phosphate buffer. Prior to cryosectioning, the tissue was saturated with $30 \%$ sucrose in a $0.1 \mathrm{M}$ phosphate buffer containing $4 \%$ paraformaldehyde.

For antibody-labeling experiments, inner-ear tissue was fixed with ice-cold $2 \%$ PLP fixative (2\% paraformaldehyde buffered with $0.1 \mathrm{M}$ monobasic sodium phosphate containing $0.1 \mathrm{M}$ L-lysine hydrochloride and $0.01 \mathrm{M}$ periodic acid, $\mathrm{pH}$ 7.4). After 3-6 h fixation at $4^{\circ} \mathrm{C}$, excess bone and connective tissue were dissected away and the specimens were rinsed for $2 \mathrm{~h}$ in ice-cold $0.1 \mathrm{M}$ phosphate buffer. The specimens were then decalcified for up to $72 \mathrm{~h}$ at $4^{\circ} \mathrm{C}$ in $5 \%$ EDTA buffered with $0.1 \mathrm{M}$ phosphate buffer. Following several rinses $(1-3 \mathrm{~h})$ in fresh $0.1 \mathrm{M}$ phosphate buffer, the tissue samples were cryoprotected with $30 \%$ sucrose in 0.1 $\mathrm{M}$ monobasic phosphate for a minimum duration of $48 \mathrm{~h}$ at $4^{\circ} \mathrm{C}$.

For both in situ hybridization and immunohistology staining, the ensemble of sections collected from each temporal bone was distributed through 12-24 slides (12-15 sections per slide) depending on the age of the animal (the larger ears of older animals requiring more slides). The collection of the tissue sections onto the slides was performed in a serial manner that permitted us to have on each slide a reliable representation of the whole length of the basilar papillae (first tissue section on slide numbered 1 and the following tissue section on slide numbered 2 and so forth). Such 
a cryosectioning paradigm provided uniformity of treatment for cross sections throughout the cochlear length so that differences in staining intensity between apical and basal sections or between different tissue types (for both in situ hybridization and immunostaining) indicate real cellular variability.

\section{Semiquantitative RT-PCR}

The corresponding quadrants from four microdissected papillae (containing only the sensory hair cells and their immediate surrounding supporting cells) were pooled. Complementary DNA was synthesized from each pool in a $20 \mu \mathrm{L}$ volume using a mixture of AMV (avian myeloblastosis virus) and Superscript II reverse transcriptase (both from Invitrogen, Carlsbad, CA, USA). The reverse transcription (RT) products were diluted ten-fold and $1 \mu \mathrm{L}$ aliquots were then used as template cDNA for each subsequent PCR assay. The same diluted RT mix was used for duplicate PCRs and for both calbindin and $\beta$-actin. Unlabeled nucleotides were included at $2 \mu \mathrm{M}$ each, and $1 \mu \mathrm{Ci}$ of $\alpha{ }^{32} \mathrm{P}-\mathrm{dCTP}$ was added to each PCR to label the products. Cycle parameters were $94^{\circ} \mathrm{C}$ for $1 \mathrm{~min}, 55^{\circ} \mathrm{C}$ for $2 \mathrm{~min}, 72^{\circ} \mathrm{C}$ for $3 \mathrm{~min}$. Primer pairs for both $\beta$-actin and calbindin were designed so that they spanned intronic sequences, and 100 pmol of each primer was used in each PCR. The expected sizes of the PCR products for calbindin and $\beta$-actin were 213 and $158 \mathrm{bp}$, respectively. Radiolabeled PCR products were separated by polyacrylamide gel electrophoresis and the radioactivity in each band was determined using a PhosphoImager. Each PCR amplification was determined to be in the exponential phase at 30 cycles when the final measurement of products was made. The consistency in amplification procedure was addressed by performing each amplification in duplicate and by repeating the experiment three times. PhosphoImager bands were digitized and analyzed in Adobe Photoshop. The perimeter of each band was defined and the average pixel density within that area determined. Band "weight" was taken as the product of area and average optical density. This method underestimates signal magnitude where label intensity saturates the imager, but this was somewhat compensated by the greater area of the intense bands.

\section{In situ hybridization}

Probe synthesis. A pBluescript plasmid containing 263 bp of calbindin D-28k cDNA from the $3^{\prime}$ end of the coding region was generated from a near full-length calbindin cDNA isolated from a chick cochlear cDNA library (Oberholtzer et al. 1994). The nucleotide sequence of the chick cochlear cDNA insert matched exactly the sequence of the corresponding portion of the calbindin D-28k cDNA previously isolated from the chick's gut (Hunziker 1986). Antisense and sense riboprobes were synthesized using T3 and T7 polymerases, respectively. In vitro transcription was performed to generate digoxigenin-conjugated cRNA probes using the Genius kit (Roche Molecular Biochemicals, Indianapolis, IN, USA). After $2.5 \mathrm{~h}$ incubation at $37^{\circ} \mathrm{C}, 20$ units of RNase-free DNase I were added to the mixture and incubated for an additional $10 \mathrm{~min}$ at $37^{\circ} \mathrm{C}$ in order to degrade the linearized cDNA and stop the synthesis reaction. The generated cRNA was then denatured at $70-75^{\circ} \mathrm{C}$ for $10 \mathrm{~min}$ (this step also deactivates DNase I enzyme), precipitated with $4 \mathrm{M}$ lithium chloride and absolute ethanol, and stored at $-80^{\circ} \mathrm{C}$ until use.

Hybridization. Tissue sections were postfixed for 15 min with ice-cold $4 \%$ paraformaldehyde in $0.1 \mathrm{M}$ phosphate buffer ( $\mathrm{pH} 7.4$ ). After several washes the sections were treated with proteinase $\mathrm{K}$ at $2 \mu \mathrm{g} / \mathrm{mL}$ in $100 \mathrm{mM}$ Tris-base, $50 \mathrm{mM}$ EDTA solution $\left(\mathrm{pH} \mathrm{8.0)}\right.$ at $37^{\circ} \mathrm{C}$ for $25 \mathrm{~min}$, followed by acetylation in $0.1 \mathrm{M}$ triethanolamine $(\mathrm{pH} 8.0)$ containing $0.25 \%$ acetic anhydride. Lastly, the tissue sections were dehydrated in graded ethanol washes and air-dried under vacuum for $2 \mathrm{~h}$ at room temperature. The sections were layered with $120-150 \mu \mathrm{L}$ of the probe solution at a concentration of $0.5 \mu \mathrm{g} / \mathrm{mL}$ in hybridization buffer. The hybridization step was then carried out at $58^{\circ} \mathrm{C}$ for $16-18 \mathrm{~h}$. Following several washes in $4 \times$ SSC buffer $(1 \times$ SSC is $15 \mathrm{mM}$ sodium citrate and $150 \mathrm{mM}$ sodium chloride, $\mathrm{pH}$ 7.0), the tissue sections were treated with RNase $\mathrm{A}$ at $20 \mu \mathrm{g} / \mathrm{mL}$ in $10 \mathrm{mM}$ Tris-base, $500 \mathrm{mM} \mathrm{NaCl}$, and $1 \mathrm{mM}$ EDTA ( $\mathrm{pH}$ 8.0) to hydrolyze single-stranded nucleic acids such as unbound riboprobe molecules. Thereafter, they were washed at room temperature in decreasing concentration of SSC solution followed by a final rinse in $0.1 \times \mathrm{SSC}$ at $50^{\circ} \mathrm{C}$.

Signal immunodetection. To block nonspecific labeling, the tissue sections were treated for $1 \mathrm{~h}$ at room temperature with $5 \%$ normal sheep serum (Sigma, St. Louis, MO) in $100 \mathrm{mM}$ Tris-base, $150 \mathrm{mM} \mathrm{NaCl}$ containing $0.25 \%$ Triton $\mathrm{X}-100$ at $\mathrm{pH}$ 7.5. Subsequently, the tissue sections were incubated with alkaline phosphatase-conjugated antidigoxigenin antibody diluted 1:500 in the blocking solution for $2.5 \mathrm{~h}$ at room temperature. After two washes in $100 \mathrm{mM}$ Tris-base, $150 \mathrm{mM} \mathrm{NaCl}$ ( $\mathrm{pH} 7.5$ ), the tissue sections were rinsed twice for $10 \mathrm{~min}$ in $100 \mathrm{mM}$ Tris-base, 100 $\mathrm{mM} \mathrm{NaCl}$, and $50 \mathrm{mM} \mathrm{MgCl}_{2}$ (pH 9.5). Finally, for alkaline phosphatase activity detection, the tissue sections were placed in $100 \mathrm{mM}$ Tris-base, $100 \mathrm{mM} \mathrm{NaCl}$, and $50 \mathrm{mM} \mathrm{MgCl}_{2}$ (pH 9.5) containing $0.50 \mathrm{mg} / \mathrm{mL}$ nitroblue tetrazolium phosphate-buffered saline and $0.19 \mathrm{mg} / \mathrm{mL}$ 5-bromo-4-chloro-3-iodolyl phosphatase (Boehringer, Mannheim, Germany) for overnight incubation at room temperature. After brief washes 
in de-ionized water to stop the alkaline phosphatase activity, the slides were air-dried and mounted for light microscopy observations and data analysis.

\section{Calbindin D-28k immunohistochemistry}

The slides were heated at $37^{\circ} \mathrm{C}$ for $15-30$ min to allow tissue sections to adhere strongly to the slide surface, avoiding any tissue loss during the multiple washes of the procedure. To reduce nonspecific labeling caused by endogenous peroxidases the tissue sections were treated for 15-30 minutes with 3\% hydrogen peroxide and $10 \%$ methanol in $50 \mathrm{mM}$ phosphate-buffered saline (PBS). Thereafter the tissue sections underwent several rinses in $50 \mathrm{mM}$ PBS ( $\mathrm{pH}$ 7.4). Prior to the primary antibody incubation, the slides were placed for $1 \mathrm{~h}$ at room temperature in the blocking buffer which consisted of $50 \mathrm{mM}$ PBS ( $\mathrm{pH}$ 7.4) supplemented with 5\% normal goat serum and $0.25 \%$ Triton X-100. Anti calbindin D-28k antibody $(300 \mu \mathrm{L})$ [C8666, a mouse monoclonal raised against chick calbindin D28k (Sigma Immunochemicals, St. Louis, MO, USA) ] diluted at 1:2000 were layered on each slide. The slides were then placed at $4^{\circ} \mathrm{C}$ in humid chambers for an overnight incubation. After two rinses in the blocking buffer, the tissue sections were treated with streptavidin-conjugated goat antimouse IgG (Jackson Immunochemicals, West Grove, PA, USA) at 1:4000 dilution for $2 \mathrm{~h}$ at room temperature. Following several washes in $50 \mathrm{mM}$ PBS containing $0.25 \%$ Triton X-100 (pH 7.4), the tissue sections were incubated for $1 \mathrm{~h}$ at room temperature with HRP-conjugated avidin-biotin complex (ABC Elite kit, Vector Laboratories, Burlingame, CA, USA) and then underwent a series of washes at room temperature in $50 \mathrm{mM}$ PBS $(\mathrm{pH} \mathrm{7.4)}$ prior to the chromogenic reaction. For signal visualization, the tissue sections were placed in $0.04 \%$ daminobenzidine and $0.03 \%$ hydrogen peroxide in $50 \mathrm{mM}$ PBS solution until an adequate signal/background ratio was reached. The reaction was then stopped with multiple brief rinses in de-ionized water, and finally the slides were prepared for light microscopy examination.

\section{RESULTS}

\section{Semiquantitative RT-PCR}

Four basilar papillae were subdivided and pooled by quadrant of sensory epithelium for reverse transcription of isolated RNA. The resulting cDNA was split and amplified using specific primers for calbindin and $\beta$-actin. Each reaction was run in duplicate and the PCR products separated using polyacrylamide gel electrophoresis. The expected size of the PCR products for calbindin and $\beta$-actin were 213 and $158 \mathrm{bp}$, respectively. Figure 1 shows the pattern of radiolabeled products obtained from each of four cochlear quadrants as illustrated in the schematic drawing with the gels. The magnitude of the $\beta$-actin product reflects the relative size of the basilar papilla, which is approximately 40 hair cells wide at the apex but as few as 10 cells wide in the base. Clearly, a much larger $\beta$-actin PCR product was obtained in apical quadrants. In marked contrast, the calbindin PCR product was largest in those reactions run on basal quadrants of the cochlea. The average signal intensity of each labeled band was measured digitally and multiplied by the area of that band to give a band "weight." The ratio of calbindin to $\beta$-actin weight was calculated for each quadrant. The calbindin-to- $\beta$-actin ratios varied from 0.2 to 0.5 to 1.3 to 2.2 , proceeding from apicalmost to basalmost quadrants. That is, calbindin expression appeared to increase relative to $\beta$-actin as one proceeds from low- to high-frequency regions of the cochlea. This result extends earlier work in which a calbindin PCR product was shown to be quantitatively larger in basal halves of the cochlea (Navaratnam et al. 1995) and raises the question of which cell types in the basilar papilla are responsible for this calbindin expression gradient.

\section{In situ hybridization and immunohistology}

Before describing these results it should be emphasized that each experiment was conducted on serial sections of the cochlear duct collected onto single slides. Thus, the differences in label intensity along the cochlear length were observed in different sections on one slide, each having received identical treatment. Likewise, the vestibular end organs were found in these same temporal bone sections, so that differential labeling there also can be attributed to biological rather than experimental variability. One drawback of using the entire temporal bone is that the plane of section could not be varied to compensate for the curvature of the basilar papilla. Thus, some views presented below were not strictly orthogonal to the long axis of the basilar papilla, especially at the apical and basal extremes of the cochlear duct.

Figure 2 shows a schematic cross section of the avian auditory end organ to serve as an orientation reference for the figures described below. This schematic was traced on transparencies using a cochlear cross section (midfrequency region) as a model. Thereafter, the drawings were scanned and processed to visualize the different cell types present in the cochlear duct.

In situ hybridization using a riboprobe for calbindin revealed expression of its mRNA in both hair cells and supporting cells of the chick's basilar papilla (Fig. 3). Although both cell types expressed calbindin, label 


\section{Calbindin}

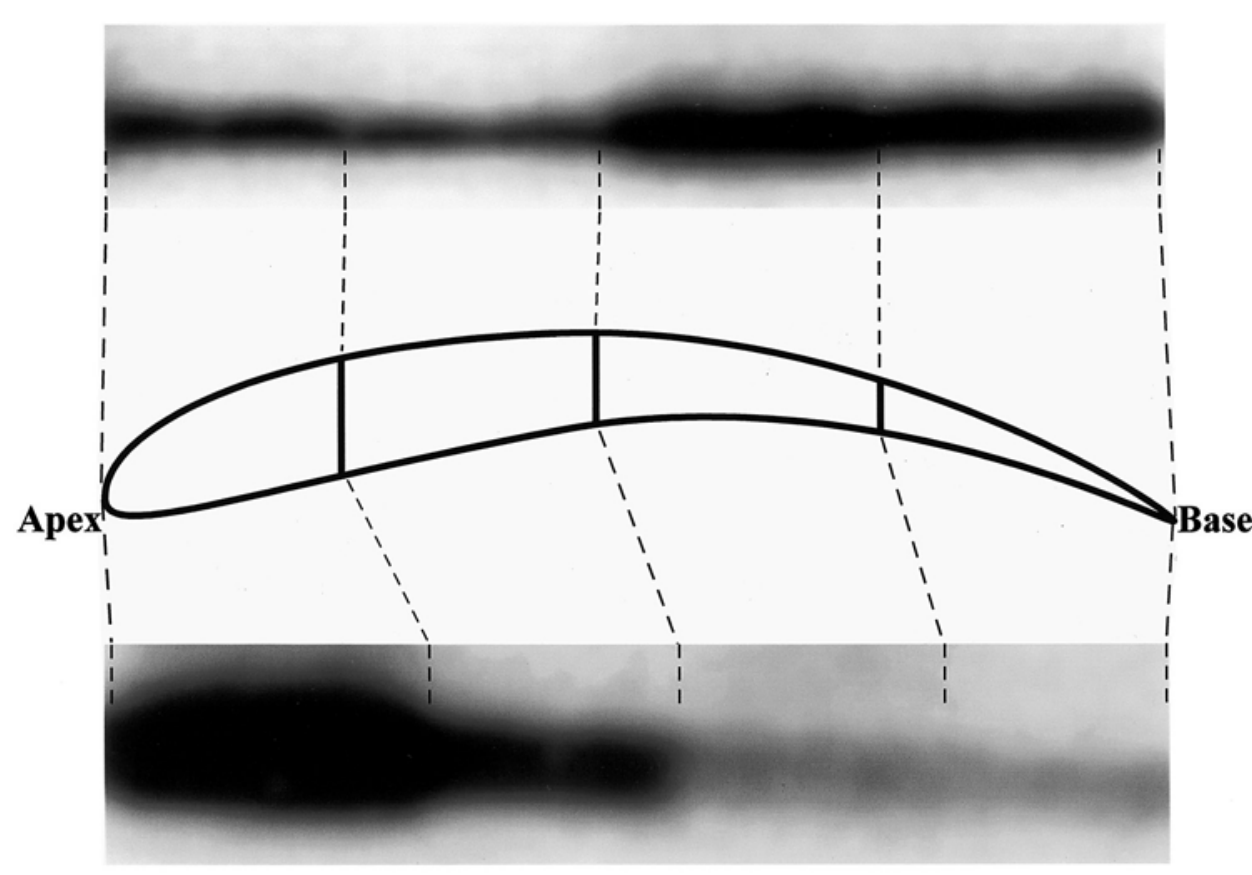

$\beta$-Actin
FIG. 1. RT-PCR using RNA isolated from the microdissected basilar papilla of the chick. Four basilar papillae were microdissected into quadrants, the RNA pooled for each quadrant, then split to provide template for amplification by PCR with primers specific to chick calbindin and $\beta$-actin. Radiolabeled PCR products were isolated by gel electrophoresis and visualized using a Phospholmager. The ratio of calbindin to $\beta$-actin rose continuously from the apicalmost to the basalmost quadrant. intensity was generally higher in hair cells than in supporting cells and the pattern of expression in the two cell types differed systematically along the length of the basilar papilla. Calbindin mRNA was present at the highest levels in hair cells nearest the cochlear base, the high-frequency end of the tonotopic axis. The intensity of the alkaline phosphatase reaction product used to detect the digoxigenin-labeled riboprobe fell progressively in sections taken from successively more apical positions. The relative opacity (the "darkness," not corrected for background) of hair cells in the middle third of each cross section varied from $77 \%$ to $66 \%$ to $44 \%$ of saturation, progressing from the basalmost to the apicalmost sections (Fig. 3). In addition to variations in label intensity along the length of the basilar papilla, there often appeared to be denser labeling of tall hair cells than of short hair cells, especially in basal sections.

Calbindin mRNA also was present in the supporting cells that surround and underlie the hair cells in the basilar papilla. An especially strong label was seen in those supporting cells lying on the basilar membrane itself (especially beneath short hair cells), as distinct from those supporting cells found on the neural limbus (below tall hair cells). Neurons in the associated cochlear ganglion throughout most of the cochlear duct were not labeled with the calbindin probe. Hair cells and supporting cells were unlabeled in control sections incubated with the "sense" probe (Fig. 3).
The vestibular end organs revealed a markedly different pattern of calbindin in situ hybridization. In contrast to the basilar papilla, hair cells in saccule (Fig. 4A), utricle, and semicircular canals were entirely negative for calbindin mRNA. However, in the same sections a subset of larger vestibular neuronal somata were strongly calbindin mRNA positive (Fig. 4B). Additional evidence for the differential expression of calbindin was obtained using a monoclonal antibody to chick calbindin.

In agreement with the in situ hybridization result, hair cells and supporting cells in the basilar papilla were heavily labeled with the calbindin antibody (Fig. 4C). Cochlear ganglion neurons and axons were not labeled. However, in the apical portion of the duct a few large neurons were found that were calbindin immunopositive (arrowheads, Fig. 4C). These were separated from the main body of the ganglion by fascicles of axons and correspond in appearance and position to lagenar afferent neurons as described by Fischer et al. (1994). In situ hybridization revealed calbindin mRNA in similarly disposed large neurons in apical sections of the cochlear duct (not shown).

Vestibular end organs treated with calbindin antibody showed a pattern of label complementary to that of the auditory organ. With the possible exception of very light labeling of hair cells in the periphery of the cristae of the semicircular canals, the calbindin antibody (Fig. 4D) did not label vestibular hair cells. 


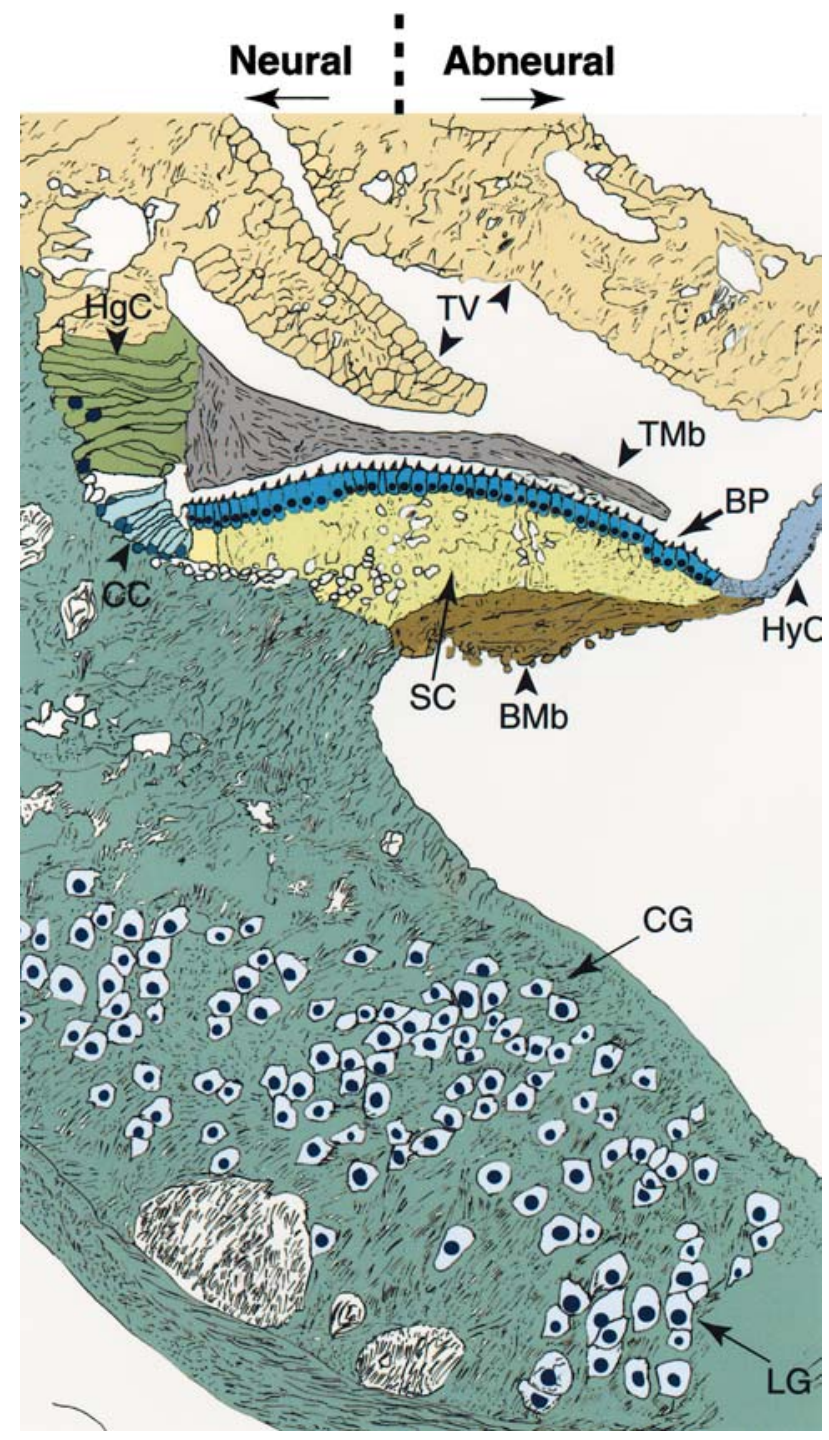

FIG. 2. Schematic of a cross section from chick cochlear duct. Tracings were made from a photographic enlargement of a midregion cross section of the chick cochlear duct. The tracings were scanned and color-coded to indicate each cell type. The vertical dotted mark indicates the dividing line between neural and abneural regions of the basilar papilla. Abbreviations: BMb, basilar membrane; BP, basilar papilla; CC, clear cells; CG, cochlear ganglion neurons; $\mathrm{HgC}$, homogene cells; HyC, hyaline cells; LG, lagenar ganglion neurons; SC, supporting cells; TMb, tectorial membrane; TV, tegmentum vasculosum.

While little or no hair cell labeling was seen, largediameter axons giving rise to complex synaptic endings in the saccular epithelium were labeled (Fig. 4D) (similar patterns were observed in all the vestibular organs). Although this low-power view may give the impression of some hair cell labeling, closer examination showed that this was due to out-of-focus afferent endings labeled deeper in the $16 \mu \mathrm{m}$ thick section. Indeed, a higher-power view showed that most of the labeled endings were clearly calyciform and could be seen to surround unlabeled hair cells (Fig. 4E, asterisk).

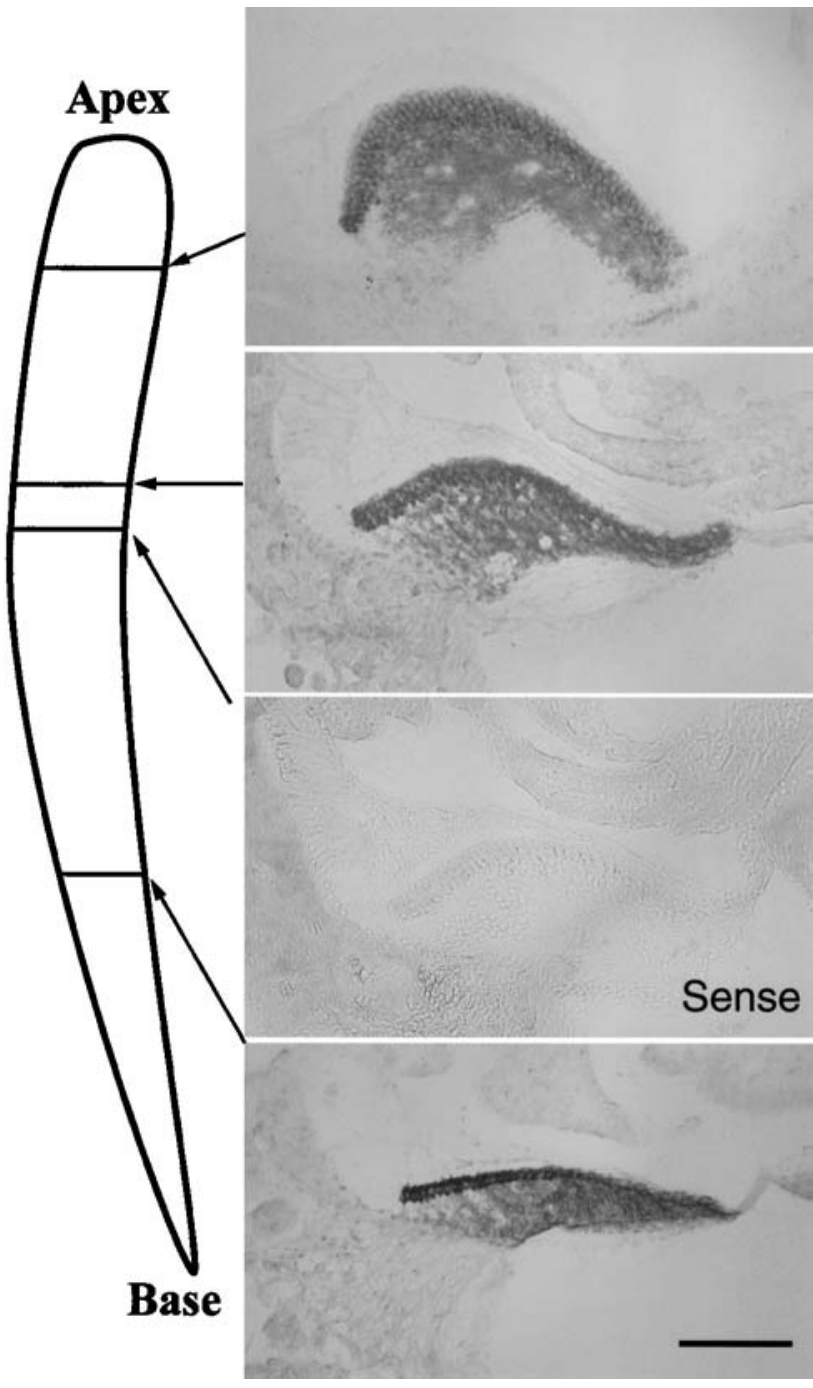

FIG. 3. Nonisotopic in situ hybridization (alkaline phosphatase reaction) using a calbindin riboprobe (263 bp) applied to serial sections from the basilar papilla of the chick. The location of each panel is indicated on the schematic of the basilar papilla; it ranged from apicalmost on top to basalmost on the bottom. The in situ hybridization signal is heaviest in hair cells in the base, and lightest in hair cells in the apex. In addition, supporting cells in each section also were labeled. The third panel shows the "sense" control. Scale bar is $100 \mu \mathrm{m}$ and applies to all panels.

Consistent with the in situ hybridization results, the calbindin antibody (Fig. 4F) also labeled a subset of neuronal cell bodies and axons in the vestibular ganglion. Approximately 25\% of the neurons in a given section labeled strongly for calbindin protein (or mRNA). These tended to be the larger somata in each section, as would be expected if they gave rise to the large-caliber, calyx-forming axons seen in the epithelium itself.

\section{Calbindin expression in the embryonic cochlea}

We chose next to examine the embryonic cochlea in an attempt to learn how, during development, the 

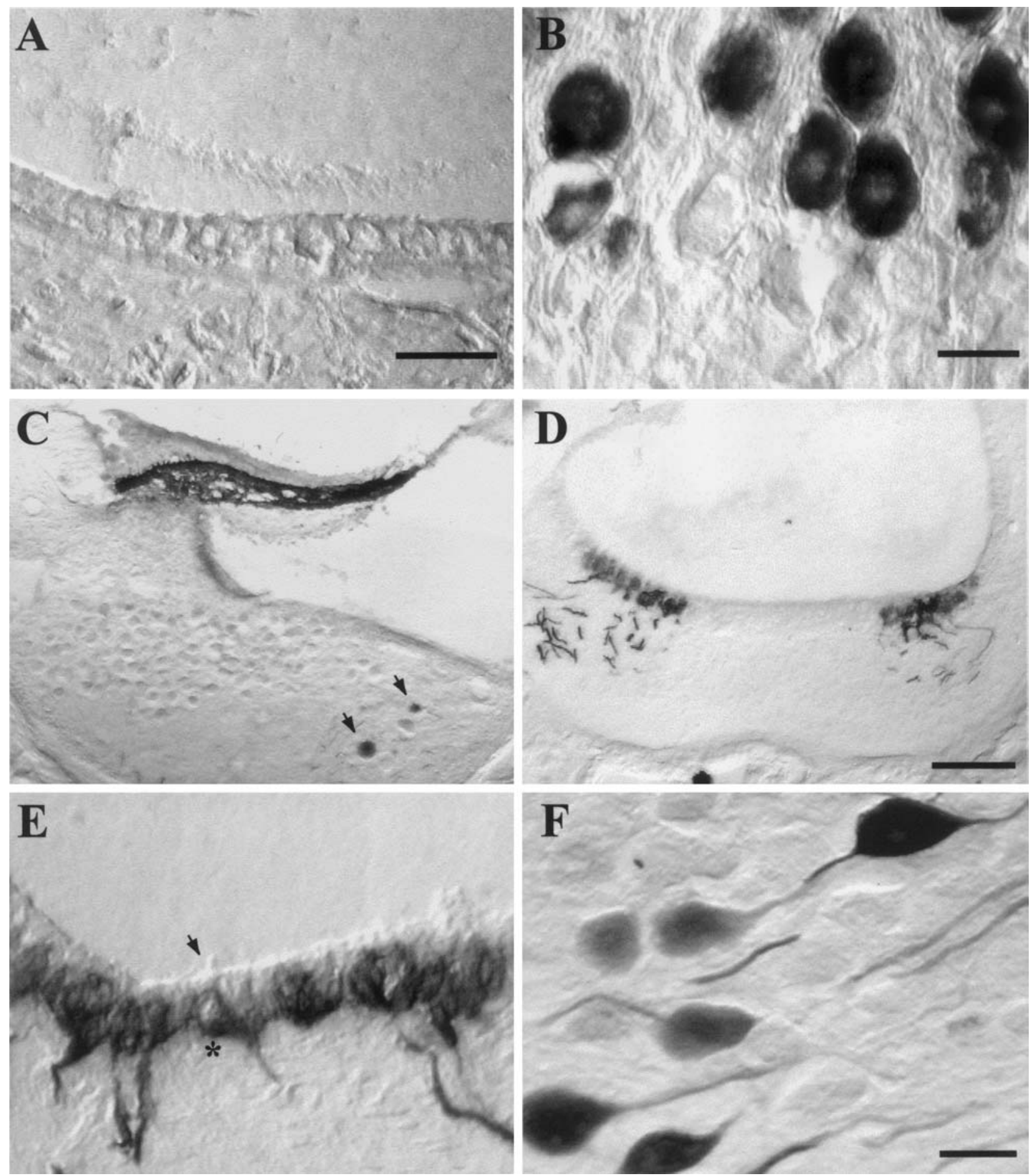

FIG. 4. Calbindin in situ hybridization and immunohistology in the cochlear and vestibular end organs. An antisense riboprobe for calbindin mRNA and a mouse monoclonal antibody to chick calbindin were used to label sections of chick temporal bone. A. In situ hybridization. Cross section of the saccular epithelium shows the absence of hybridization signal for calbindin mRNA in both hair cells and supporting cells. Ampullar and utricular epithelia were similarly devoid of hybridization signal. B. In situ hybridization. In contrast, a subset of neurons in the vestibular ganglion showed strong expression of calbindin mRNA. C. Immunohistology. A monoclonal antibody to calbindin strongly labeled hair cells and supporting cells of the basilar papilla, while somata and axons of ganglionic neurons were not labeled.

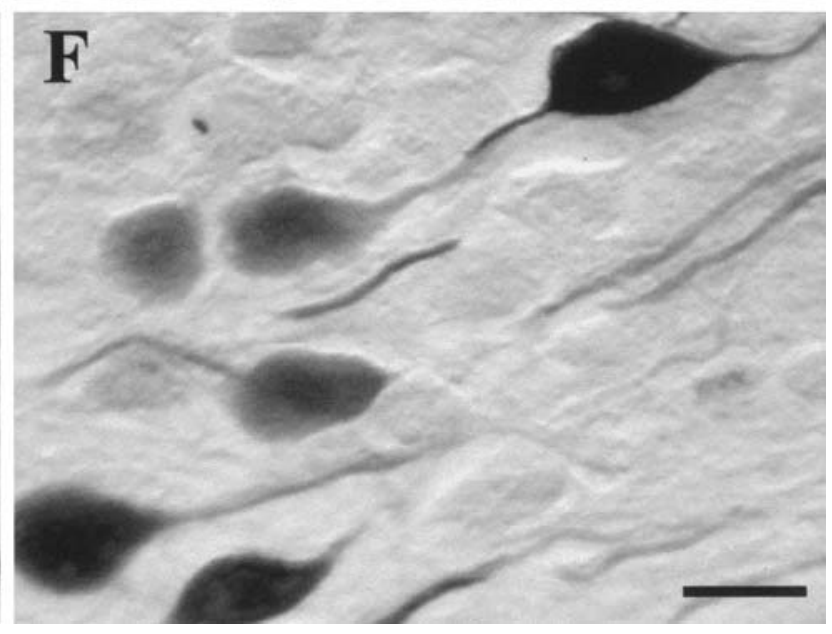

Arrows point to lagenar afferents that were labeled. D. Immunohistology. Large axons and calyciform endings in the saccular epithelium were immunopositive. Vestibular hair cells showed little or no immunolabel. A dense network of calyciform endings is out of focus in this region and gives the appearance of diffuse label. E. Higherpower view of calbindin immunoreactivity in the utricle. Complex calyciform endings are labeled, hair cells are not. The arrow indicates the bundle atop one hair cell. The unlabeled cytoplasm of that hair cell can be seen within the labeled filigree of the synaptic ending (asterisk). F. Vestibular neurons labeled with calbindin antibody. A and $\mathbf{B}$ scale bars $=50$ and $25 \mu \mathrm{m}$, respectively. C and D scale bar $=100 \mu \mathrm{m}$. $\mathbf{E}$ and $\mathbf{F}$ scale bar $=25 \mu \mathrm{m}$. 
spatial or topological organization of calbindin expression is established. Cross sections were made of cochleas from embryonic days 10, 12, 16, and 20 (hatching occurs on day 21). These were processed for calbindin in situ hybridization as above, while others were processed for immunohistology using the monoclonal calbindin antibody. At embryonic day 10 (E10), more than $90 \%$ of the hair cells have appeared (Tilney et al. 1986) and contacts with afferent neurites can be observed (Whitehead and Morest 1985a, b; Rebillard and Pujol 1983). In situ hybridization revealed strong labeling of hair cells in a section taken in the basal quarter of the E10 papilla (Fig. 5). The alkaline phosphatase reaction product was excluded from the nucleus, concentrating especially in the synaptic pole of the cell, with lesser amounts near the cuticular plate (Fig. 6). Lighter but distinctive label was also present in supporting cells between the hair cells and the basilar membrane. Antibodies to calbindin did not show labeling above background (Fig. 5).

In situ hybridization of a section collected from the apical quarter of the E10 papilla produced a punctate distribution of label (Fig. 5). This was significantly less than that seen in the base but it too was concentrated in the subnuclear or synaptic pole of the cells (Fig. 6). A diffuse pattern of label was seen in the supporting cell zone between the hair cells and the basilar membrane. Calbindin immunohistology showed no specific label in the cochlear apex at this age.

A section taken from the basal quarter of the E12 papilla was labeled more densely by in situ hybridization (Figs. 5 and 6). The colored reaction product nearly filled each hair cell, up to and including the cuticular plate, and even obscured the nucleus in the shortest hair cells on the abneural margin of the papilla. Reaction product also was obvious in the supporting cell region, especially concentrated in those cells on the abneural half of the papilla. The supporting cell in situ signal was stronger than that seen at E10. A portion of the tegmentum vasculosum (the avian stria vascularis) is visible in the upper-right-hand portion of this micrograph. This structure was negative for calbindin in situ hybridization throughout these studies. Immunohistology with calbindin antibodies showed convincing labeling of hair cells in the E12 base (Fig. 5). Every hair cell was labeled equally well, with some concentration of signal in the basal pole (visible with higher-power examination). Supporting cells did not appear to be labeled by the antibody at this age.

Calbindin in situ hybridization produced stronger labeling in the E12 apex than was seen at E10 (Figs. 5 and 6). In fact, the signal density was similar to that seen in the papillar base at E10. Reaction product filled the cell interior, with the exception of the nucleus, and was prominent in both the synaptic and cuticular poles of the cells (Fig. 6). Here, as in other sections, the pattern of hair cell labeling was impressively discrete. Both the neural and abneural boundaries of label were very sharp (Fig. 5). There was no suggestion of signal in clear cells and homogene cells (Oesterle et al. 1992) adjacent to the tall hair cells [neural (left) margin]. On the abneural (right) margin, the label stopped with the last short hair cell, with border cells and hyaline cells left unlabeled (Fig. 5). However, as elsewhere, supporting cells beneath the hair cells were strongly labeled in this section, again with a concentration of label in those supporting cells overlying the basilar membrane. A very clear boundary is seen at the juncture of the basilar membrane with the neural limbus which corresponds to the location of the habenula perforata (the access point for axonal processes into the papilla). Supporting cells to the left of that boundary, lying over the neural limbus, were not labeled. Immunohistology with calbindin antibodies produced very light labeling of hair cells but none in supporting cells in the E12 apex.

At E16, both in situ hybridization and immunohistology produced high levels of signal in the papillar base (Fig. 7). Hair cells were uniformly labeled by both methods across the width of the papilla. Supporting cells lying over the basilar membrane-but not those over the neural limbus-were labeled for both calbindin mRNA and protein. Thus, little change in calbindin expression occurred between E12 and E16 in the papillar base, with the exception that calbindin protein in supporting cells was now detected by immunohistology.

Likewise, in the cochlear apex at E16, calbindin expression could be detected in hair cells and supporting cells by both in situ hybridization and immunohistology (Fig. 7). The general pattern of distribution was
FIG. 5. In situ hybridization and immunohistology for E10 and E12 embryos. Upper four panels show representative cross sections from the base (left) and apex (right) exposed to calbindin riboprobe (ISH upper row) or antibody (IM - lower row). Calbindin mRNA is readily detected in hair cells and supporting cells of the cochlear base (upper left) but is present at lower levels in the cochlear apex (upper right) (alkaline phosphatase reaction). Antibody labeling (horseradish peroxidase) is not obviously above background in apex or base at E10 (second row). Third row of panels shows results from in situ hybridization at E12 (ISH). Basal hair cells and supporting cells are heavily labeled, those in the apex are labeled more lightly. However, the apical in situ hybridization is now substantially heavier than that E10. Fourth row of panels shows calbindin immunohistology in the base (left) and apex (right) at E12 (IM). Basal hair cells are clearly labeled but the supporting cells are not. Apical hair cells may be just above background. Scale bar $=50 \mu \mathrm{m}$ for all panels. 


\section{Base}

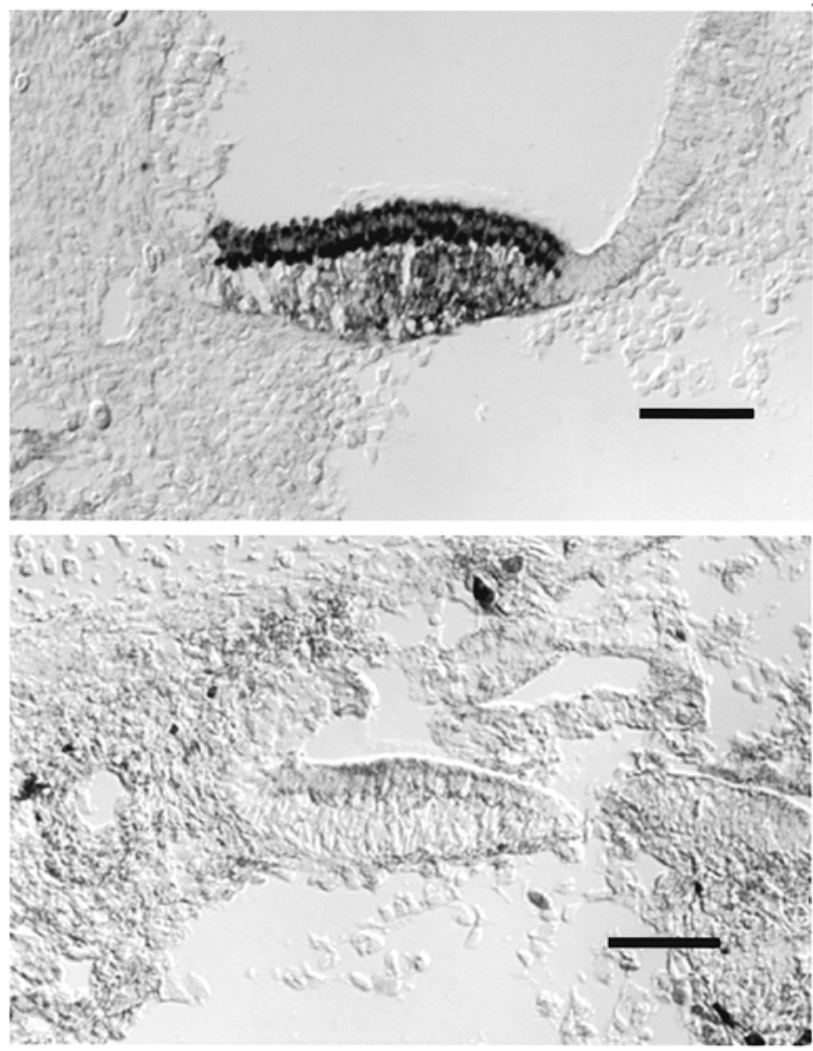

E10

\section{ISH}

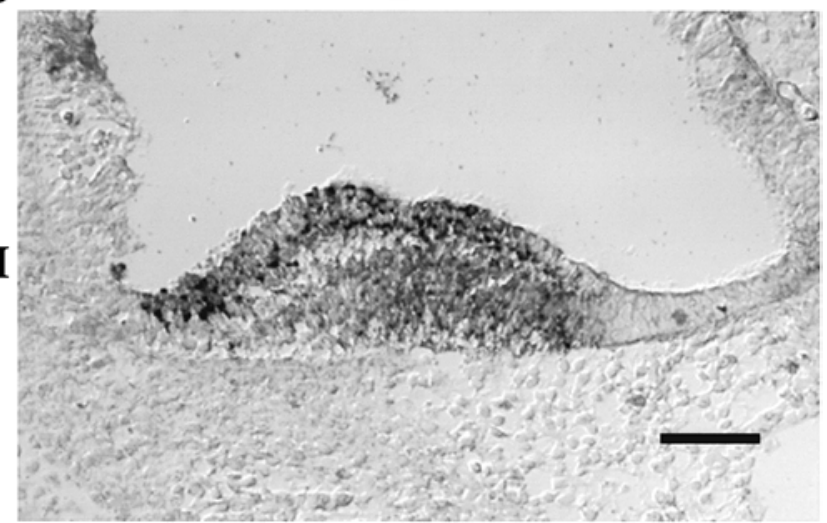

IM
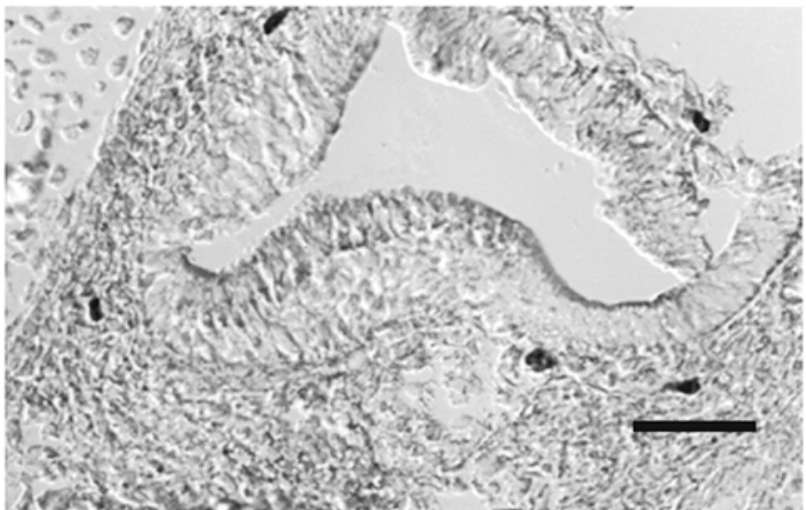

E12
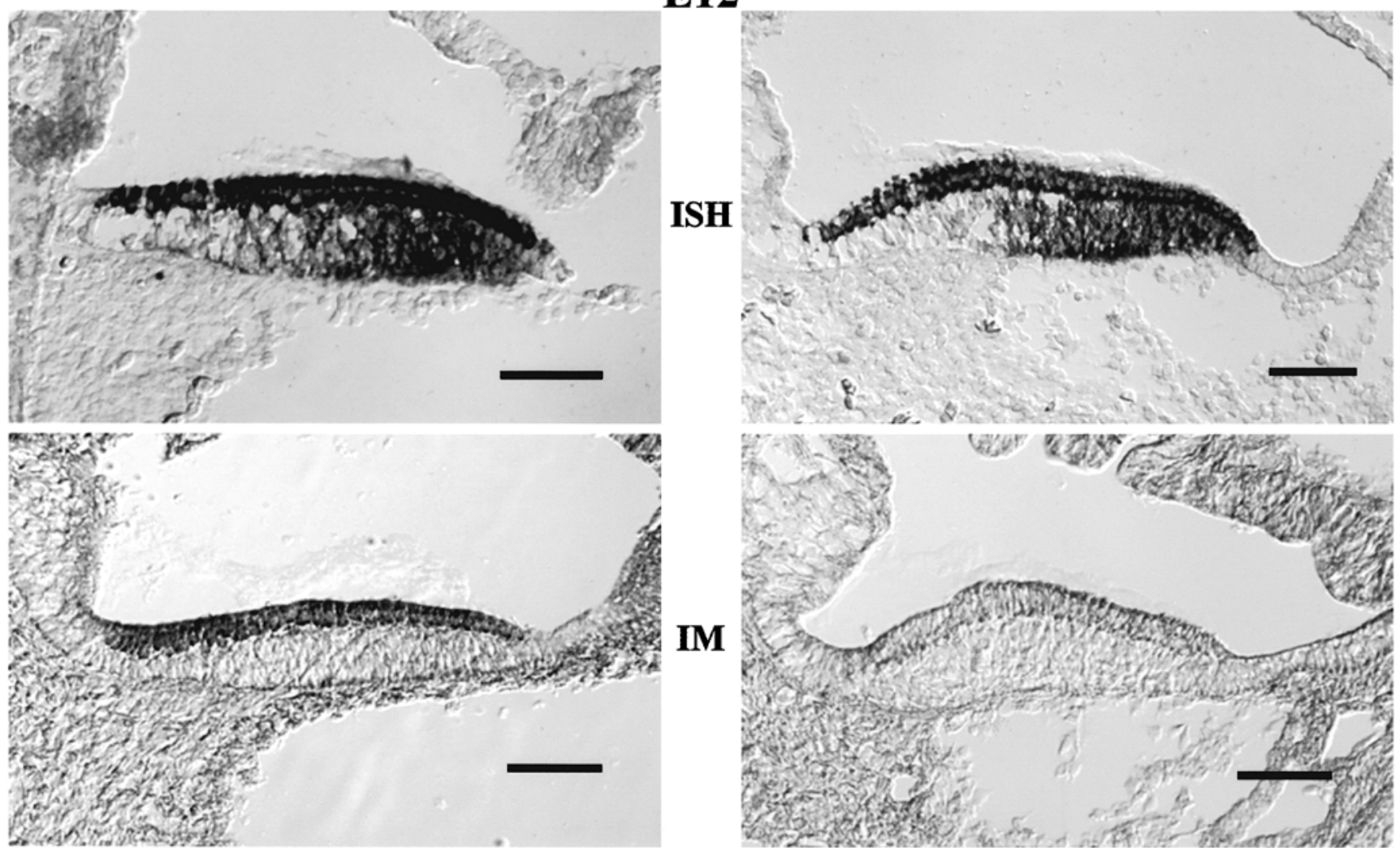


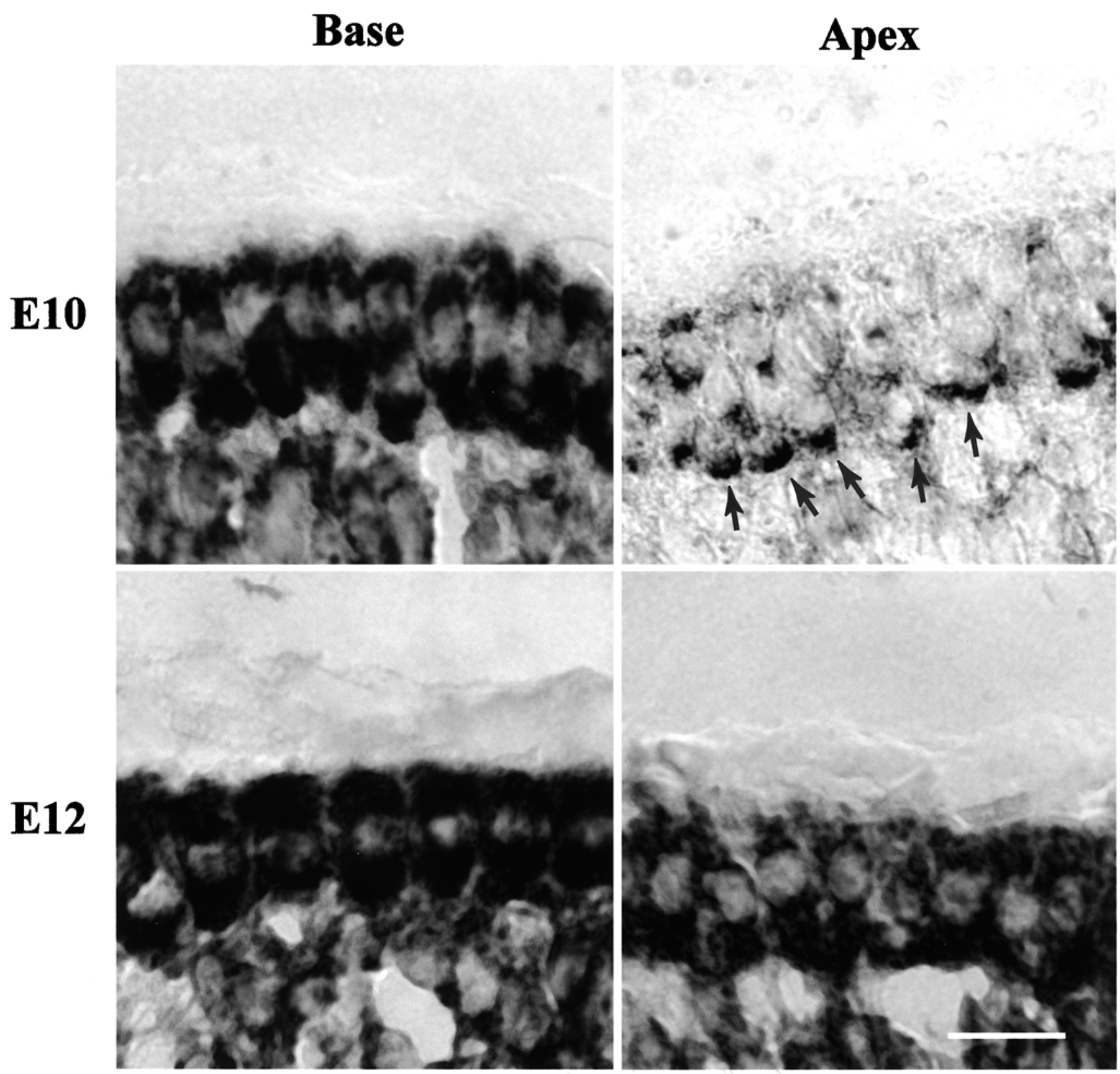

FIG. 6. High-magnification micrographs of basal and apical cross sections to show details of calbindin mRNA expression by in situ hybridization in E10 and E12 embryonic hair cells. Upper panels show the difference in expression of calbindin between basal (left) and apical (right) hair cells at E10. The synaptic poles of basal hair cells were particularly heavily labeled. In the apical sensory cell, calbindin mRNA expression was significantly less than that seen in the base but was also concentrated in the subnuclear or synaptic

similar to that previously established. Hair cells were labeled uniformly across the width of the papilla. Supporting cells lying over the basilar membrane-but not those over the neural limbus-were labeled. The intensities of both the in situ and the immunohistology labels were not as great as those observed in the papillar base at E16. The section used for immunohistology pole of the cells. Arrows indicate the basal area of the cell body where calbindin mRNA first appeared. As a result of the curvature of the epithelium, more than one row of hair cells is visible in the section. The hair cells at E12 appear more densely labeled than those at E10. In situ hybridization signal appears stronger in the hair cells at the base. At the apex, the hybridization signal is present throughout the cytoplasm, particularly concentrated in the subnuclear synaptic region of the cell. Scale bar $=10 \mu \mathrm{m}$. was cut somewhat tangentially through the curvature of the apical end of the papilla (Fig. 7). Thus, in this panel the margins of the hair cells and the boundaries of the papilla are not as distinct as in other figures.

The pattern of in situ labeling at E20 was equivalent to that observed in the posthatch and E16 papillas as seen in Figures 3 and 7. Basal hair cells were very 


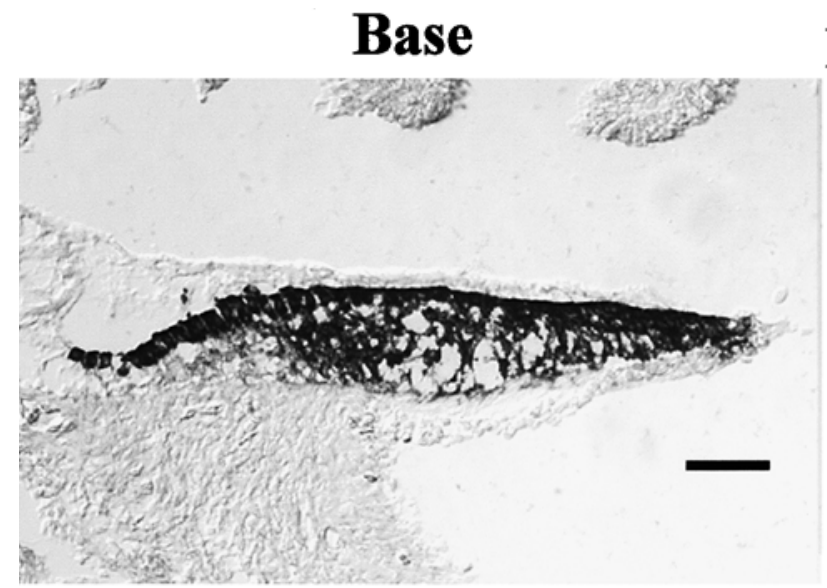

E16

Apex

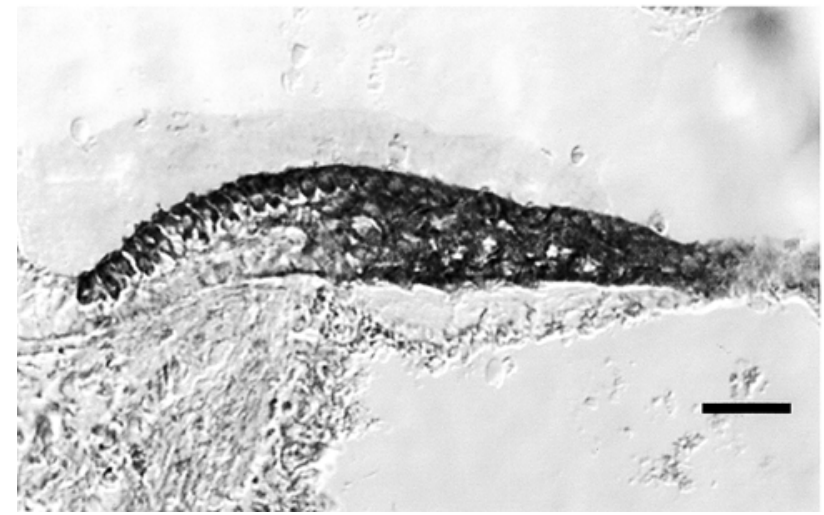

ISH

FIG. 7. Calbindin in situ hybridization and immunohistology in the E16 cochlear duct. Upper row shows sections from the cochlear base (left) and apex (right) exposed to calbindin antisense riboprobe and reacted for alkaline phosphatase (ISH). Hair cells in the base are more heavily labeled than those in the apex. Supporting cells overlying the

heavily labeled while those nearer the apex were lighter. Antibody labeling was generally consistent with the pattern established at E16. However, there was considerably higher background in these older cochleae. Preadsorbed control experiments showed that hair cell and supporting cell labels were specific, since no or only little signal remained after that treatment. On the other hand, lighter labeling of the tegmentum vasculosum and cochlear ganglion neurons persisted, arguing against the specificity of those signals.

\section{DISCUSSION}

\section{Localization of calbindin}

Calbindin is expressed in hair cells and supporting cells of the chick's basilar papilla (cochlea) as shown by both in situ hybridization and immunohistology. The level of expression of calbindin varies as a function of position along the cochlea's tonotopic axis: Hair cells in the high-frequency cochlear base express

higher levels of calbindin. This differs from the pattern of calbindin expression reported for the rodent cochlea in which apical hair cells have the higher levels of calbindin (Pack and Slepecky 1995; Papakostas et al. 2000). This difference may not be entirely surprising since calbindin is a far more prominent component of the avian basilar papilla than of the mammalian cochlea (Oberholtzer et al. 1986), where its roles are likely to be played by other calcium-binding proteins (Senarita et al. 1995).

Supporting cells situated over the basilar membrane itself expressed calbindin; those found over the neural limbus (underlying the tallest hair cells) appeared to express little or no calbindin, at least in the embryonic cochlea. Other nonsensory cells surrounding the basilar papilla failed to exhibit calbindin expression, including hyaline and border cells abneural to the papilla and clear cells and homogene cells flanking tall hair cells on the neural border. The tegmentum vasculosum, a secreting epithelium that is thought to produce the endolymphatic fluid (analogous in that respect to the stria vascularis of mammals) showed no in situ label for calbindin and only a nonspecific 
response to the calbindin antibody. Cell bodies of cochlear ganglion neurons were negative for calbindin in situ hybridization and had only light, nonspecific reaction to the calbindin antibody. However, large afferent neurons thought to innervate the lagena were immuno- and in situ labeled in apically originating cross sections of the cochlear duct. These could be distinguished from the cochlear afferents by their larger size and by their location as a cluster of somata separated from the cochlear neurons by fascicles of axons (Fischer et al. 1994).

The vestibular epithelia provided an interesting contrast to the situation just described for the cochlea, since both macular and cupular hair cells were negative for calbindin in situ hybridization but approximately $25 \%$ of the vestibular ganglion neurons (for the most part the larger somata) were labeled. Calbindinimmunopositive axons formed calyciform endings in restricted portions of each vestibular end organ. This situation is similar to that described for mammals in which large bipolar vestibular afferents with calyx endings also are calbindin-positive (Baird et al. 1988b; Baurle et al. 1998). This suggests that the calyx-bearing, calbindin-positive afferents in chick will have phasic response properties, as shown in mammals.

The apparent absence of calbindin in chick vestibular hair cells is in contrast to an earlier report of chick vestibular hair cell labeling with an antiserum raised against rat kidney calbindin (Dechesne et al. 1988b). Calbindin immunoreactivity also was observed in vestibular hair cells and ganglion neurons of the rat (Rabie et al. 1983), cat (Sans et al. 1986, 1987), and human (Dechesne et al. 1988a). The lack of vestibular hair cell label shown in the present study is difficult to reconcile with these earlier findings. However, the present conclusions are based on both immunohistology and in situ hybridization. Also, the antibody used here was a mouse monoclonal raised against chick calbindin and may have provided higher specificity than the polyclonal antisera used previously. Taken together, the present results suggest that calcium-binding proteins other than calbindin may predominate in chick vestibular hair cells. Indeed, a recent study shows that frog saccular hair cells label specifically with monoclonal antibodies to calretinin but not to calbindin (Edmonds et al. 2000), consistent with the results reported here. It may be relevant that polyclonal antibodies to calbindin did label frog saccular hair cells, perhaps reflecting the relatively high amino acid identity between calbindin and calretinin.

\section{Developmental regulation}

Calbindin mRNA was detected in the basilar papilla at the earliest time studied, i.e., E10, although the level of expression was considerably lower than that found in the posthatch cochlea. This earliest time point was chosen since it nearly corresponds to the time of the final cell divisions that produce hair cells (E9-E10) (Tilney et al. 1986; Katayama and Corwin 1989). From E10 onward there was a consistent pattern in which calbindin mRNA expression was clearly higher in sections taken from the basalmost quarter of the papilla compared with those arising from the apicalmost quarter, even as the expression levels rose throughout the maturing cochlea. These topological and developmental gradients were evident in the pattern of antibody labeling as well, although it was delayed relative to in situ hybridization. These results correspond to earlier work in which BPP23 (a protein later determined to be calbindin D-28k) was present at much lower levels than $\beta$-actin in the E15 basilar papilla but rose to equivalency by the time of hatching (Oberholtzer et al. 1986). In our experiments, calbindin immunoreactivity was first detectable more than a day after in situ hybridization was positive (e.g., compare the results shown for E10 and E12). This delayed appearance of calbindin immunoreactivity may be more apparent than real, however, since the antibody generated a relatively high background compared with the in situ hybridization technique and so the lowest levels of protein expression may have escaped notice. Whether delayed or not, it is clear that higher levels of calbindin protein correspond to higher levels of messenger RNA. Thus, at least some part of the regulated expression of hair cell calbindin appears to be through transcriptional regulation of the calbindin gene. The transcription of calbindin D-28k in chick intestine is activated by vitamin D (King and Norman 1986). However, in brain neurons, calbindin expression is insensitive to vitamin D levels (Ferrari et al. 1989; Hall and Norman 1991). Cerebellar Purkinje cells possess a calcium-sensitive promoter element that is necessary and sufficient for the specific expression of calbindin and calmodulin (Arnold and Heintz 1997) and future experiments should seek hair-cellspecific calbindin promoters.

Taken together, the observations on embryonic cochleae suggest that the basal-to-apical gradient of calbindin expression found posthatch results from the stabilization of a developmental gradient. Calbindin expression arose first in the cochlear base, while comparable levels of expression were reached perhaps 48 $\mathrm{h}$ later in the cochlear apex (e.g., compare in situ hybridization at E10 in the base and at E12 in the apex). Such basal-to-apical developmental gradients have been noted previously with respect to a number of other papillar features (see, e.g., Fermin and Cohen 1984) and have long been appreciated in the mammalian cochlea (Retzius 1884). Do the developmental and topological gradients in calbindin expression offer 
clues as to the mechanisms or signals that may direct the synthesis of this calcium-binding protein?

\section{Determinants of calbindin expression in the} cochlea

A number of factors could play a role in the regulation of calbindin expression; these range from exposure to morphogens such as retinoic acid (Wang and Christakos 1995; Kelley et al. 1993, Sokolowski et al. 1999) to cell birth date (Katayama and Corwin 1989). One especially likely candidate factor is that of calcium influx occurring through voltage-gated calcium channels (VGCCs) at sites of afferent synaptic contacts (Roberts et al. 1990; Issa and Hudspeth 1994; Tucker and Fettiplace 1995). Substantial currents through these channels can be recorded at least as early as E13 (Fuchs and Sokolowski 1990). Thus, it is interesting that calbindin mRNA is first observed in the subnuclear pole of the embryonic hair cells, the region in which afferent contacts first form and where the earliest presynaptic densities are observed (Hirokawa 1978b; Rebillard and Pujol 1983; Whitehead and Morest 1985a, b). Also, VGCCs increase in number with tonotopic locus in hair cells of chick (MartinezDunst et al. 1997) and turtle (Art and Fettiplace 1987), paralleling the tonotopic gradient of calbindin expression seen here. Increasing levels of calbindin may be required for buffering greater amounts of voltagegated calcium influx in higher-frequency hair cells, as suggested by estimates of cytoplasmic calcium buffering obtained from turtle hair cells (Tucker and Fettiplace 1996). This hypothesis further suggests that calbindin expression should be higher in tall (innerlike) hair cells having larger numbers of VGCCs compared with short (outerlike) hair cells with fewer VGCCs in a given cross section (Martinez-Dunst et al. 1997). While stronger calbindin immunoreactivity and in situ labeling of tall hair cells was apparent in some cross sections, a general conclusion was not possible because the unlabeled nucleus nearly fills the cytoplasmic volume of short hair cells compared with tall hair cells. The effect is to diminish the apparent density of labeling by alkaline phosphatase or horseradish peroxidase. Radiolabeled probes from which grain counts could be obtained may provide a conclusive answer to this question.

VGCCs are only one of several sources of extracellular calcium. Mechanotransducer channels in the hair bundle, and $\alpha 9$-containing, ACh-gated cation channels in the basolateral membrane also allow calcium into the hair cell. Thus, the cytoplasmic calcium load results from some combination of these sources in each hair cell, although calbindin is not necessarily the critical buffering element for each of these sources. Nonetheless, the mechanisms that regulate calbindin expression will undoubtedly be of interest in the study of hair cell differentiation in the chick's cochlea. The levels of mobile buffers will modulate calcium-dependent processes including transducer adaptation, transmitter release, and the gating of basolateral potassium channels, such as those that support electrical tuning and cholinergic inhibition in chick hair cells.

\section{ACKNOWLEDGMENTS}

This work was supported by NIDCD DC02755 to J. Oberholtzer and DC01508 to P. Fuchs.

\section{REFERENCES}

ARnold DB, Heintz N. A calcium responsive element that regulates expression of two calcium binding proteins in Purkinje cells. Proc. Natl. Acad. Sci. USA 94:8842-8847, 1997.

ART JJ, FETTIPLACE R. Variation of membrane properties in hair cells isolated from the turtle's cochlea. J. Physiol. 385:207-242, 1987.

Baird RA, Desmadryl G, Fernandez C, Goldberg JM. The vestibular nerve of the chinchilla. II. Relation between afferent response properties and peripheral innervation patterns in the semicircular canals. J. Neurophysiol. 60:182-203, 1988b.

Baurle J, Vogten H, Grusser-Cornehls U. Course and targets of the calbindin D-28k subpopulation of primary vestibular afferents. J. Comp. Neurol. 402:111-128, 1998.

Chen L, Salvi R, Shero M. Cochlear frequency-place map in adult chickens: intracellular biocytin labeling. Hear. Res. 81:130-136, 1994.

Dechesne CJ, LaVigne-Rebillard M, Brehier thomasset M, SANS A. Appearance and distribution of neuron-specific enolase and calbindin (CaBP $28 \mathrm{kDa}$ ) in the developing human inner ear Brain Res. 469:221-230, 1988a.

Dechesne CJ, Thomasset M, Brehier A, Sans A. Calbindin (CaBP $28 \mathrm{kDa}$ ) localization in the peripheral vestibular system of various vertebrates. Hear. Res. 33:273-278, 1988b.

EDMONDS B, REYES R, SCHWALLER B, RoBERTS WM. Calretinin modifies presynaptic calcium signaling in frog saccular hair cells. Nat. Neurosci. 3:786-790, 2000

Fermin CD, Cohen GM. Developmental gradients in the embryonic chick's basilar papilla. Acta Otolaryngol. (Stockh.) 97:39-51, 1984.

Ferrari S, Battini R, Drusiani E. Tissue-specific regulation of the concentration of calbindin D28k mRNA in the developing chicken. Life Sci. 45:1247-1253, 1989.

Firbas W, Muller G. The efferent innervation of the avian cochlea Hear. Res. 10:109-116, 1983.

FISCHER FP. Quantitative analysis of the innervation pattern of the chicken basilar papilla. Hear. Res. 61:167-178, 1992.

FisCher FP, EISENSAMER B, MANLEy GA. Cochlear and lagenar ganglia of the chicken. J. Morphol. 220:71-83, 1994. 
Fuchs PA, Evans MG. Potassium currents in hair cells isolated from the cochlea of the chick. J. Physiol. 429:529-551, 1990.

Fuchs PA, Murrow BW. Cholinergic inhibition of short (outer) hair cells of the chick's cochlea. J. Neurosci. 12:800-809, 1992.

Fuchs PA, NAGAI T, Evans MG. Electrical tuning in hair cells isolated from the cochlea of the chick. J. Neurosci. 8:2460-2467, 1988.

FucHS PA, SoKoLOwsKi BHAS. The acquisition during development of Ca-activated potassium current by cochlear hair cells of the chick. Proc. R. Soc. Lond. B. Biol. Sci. 241:122-126, 1990.

Gray L, Rubel EW. The development of absolute thresholds in chickens. J. Acoust. Soc. Am. 77:1162-1172, 1985.

HaCkNEy CM, FetTIPLACE R, FuRness DN. The functional morphology of stereociliary bundles on turtle cochlear hair cells. Hear. Res. 69:163-175, 1993

HALl AK, NORMAN AW. Vitamin D-independent expression of chick brain calbindin-D28k. Brain Res. Mol. Brain Res. 9:9-14, 1991.

HirokaWA N. Synaptogenesis in the basilar papilla of the chick. J. Neurocytol. 7:283-300, 1978a.

Hirokawa N. The ultrastructure of the basilar papilla of the chick. J. Comp. Neurol. 181:361-374, 1978b.

HuDSPETH AJ. Extracellular current flow and the site of transduction by vertebrate hair cells. J. Neurosci. 2:1-10, 1982.

HunZIKER W. The 28-kDa vitamin D-dependent calcium-binding protein has a six-domain structure. Proc. Natl. Acad. Sci. USA 83:7578-7582, 1986.

IssA NP, HudSPETH AJ. Clustering of $\mathrm{Ca}^{2+}$ and $\mathrm{Ca}^{2+}$-activated $\mathrm{K}^{+}$ channels at fluorescently labeled presynaptic active zones of hair cells. Proc. Natl. Acad. Sci. USA 91:7578-7582, 1994.

Katayama A, Corwin JT. Cell production in the chicken cochlea. J. Comp. Neurol. 28:129-135, 1989.

Kelley MW, Xu XM, Wagner MA, Warchol ME, Corwin JT. The developing organ of Corti contains retinoic acid and forms supernumerary hair cells in response to exogenous retinoic acid in culture. Development 119:1041-1053, 1993.

KING MW, NORMAN AW. Analysis of the mRNA coding for the chick vitamin D-induced calbindin and its regulation by 1,25-dihydroxyvitamin $\mathrm{D}_{3}$. Arch. Biochem. Biophys. 248:612-619, 1986.

MARTIN AR, FuCHS PA. The dependence of calcium-activated potassium currents on membrane potential. Proc. R. Soc. Lond. B Biol. Sci. 250:71-76, 1992

Martinez-Dunst CM, Michaels RL, Fuchs PA. Release sites and calcium channels in hair cells of the chick's cochlea. J. Neurosci. 17:9133-9144, 1997.

McNiven AI, Yuhas WA, Fuchs PA. The ionic dependence and agonist preference of an acetylcholine receptor in hair cells. Aud. Neurosci. 2:63-77, 1996.

MuRROW BW. Position-dependent expression of potassium currents by chick cochlear hair cells. J. Physiol. 480:247-259, 1994.

Navaratnam DS, Escobar L, Covarrubias M, Oberholtzer JC. Permeation properties and differential expression across the auditory receptor epithelium of an inward rectifier $\mathrm{K}^{+}$channel cloned from the chick inner ear. J. Biol. Chem. 18:19238-19245, 1995.

Oberholtzer JC, Buettger C, Summers MC, Matschinsky FM. The 28-kDa calbindin-D is a major calcium-binding protein in the basilar papilla of the chick. Proc. Natl. Acad. Sci. USA 85:33873390, 1988.

Oberholtzer JC, Cohen EL, DAVIs JG. Molecular cloning of a chick cochlea cDNA encoding a subunit of DNA replication factor C/ activator 1. DNA Cell Biol. 8:857-863, 1994.

Oberholtzer JC, Schneider Me, Summers MC, SAunders JC, MATSCHINSKY FM. The developmental appearance of a major basilar papilla-specific protein in the chick. Hear. Res. 23:161168, 1986.

Oesterle EC, Cunningham DE, Rubel EW. Ultrastructure of hyaline, border and vacuole cells in chick inner ear. J. Comp. Neurol. 318:64-82, 1992.
OFSIE MS, COTANCHE DA. Distribution of nerve fibers in the basilar papilla of normal and sound-damaged chick cochleae. J. Comp. Neurol. 370:281-294, 1996.

PACK AK, SLEPECKY NB. Cytoskeletal and calcium-binding proteins in the mammalian organ of Corti: cell type-specific proteins displaying longitudinal and radial gradients. Hear. Res. 91:119$135,1995$.

Papakostas K, Hackney CM, Furness DN. The distribution of the calcium buffer calbindin in the cochlea of the guinea-pig. Clin. Otolaryngol. 25:570-576, 2000.

Rabie A, Thomasset M, Legrand Ch. Immunocytochemical detection of calcium-binding protein in the cochlear and vestibular hair cells of the rat. Cell Tissue Res. 232:691-696, 1983.

REBILLARD M, PUJOL R. Innervation of the chicken basilar papilla during its development. Acta Otolaryngol. 96:379-388, 1983.

Retzius G. Das Gehororgan der Wilbeltiere. II. Das Gehororgan der Reptilien, der Vogel und Saugetiere. Samson and Wallin Stockholm, 1884.

RicCi AJ, FetTiPLACE R. The effects of calcium buffering and cyclic AMP on mechano-electrical transduction in turtle auditory hair cells. J. Physiol. 501:111-124, 1997.

RoBERTS WM, JaCOBs R, HudSPETH A. Colocalization of ion channels involved in frequency selectivity and synaptic transmission at presynaptic active zones of hair cells. J. Neurosci. 10:3664-3684, 1990.

Sans A, Brehier A, Moniot B, Thomasset M. Immuno-electronmicroscopic localization of 'vitamin D-dependent' calcium-binding protein (CaBP-28k) in the vestibular hair cells of the cat. Brain Res. 435:293-304, 1987.

Sans A, Etchecopar B, Brehier A, Thomasset M. Immunocytochemical detection of vitamin D-dependent calcium-binding protein (CaBP-28k) in vestibular sensory hair cells and vestibular ganglion neurons of the cat. Brain Res. 364:190-194, 1986.

Senarita M, Thalmann I, Shibasaki O, Thalmann R. Calciumbinding proteins in the organ of Corti and basilar papilla: CBP15 , an unidentified calcium binding protein of the inner ear. Hear Res. 90:169-175, 1995.

SOKOlowski BHA, Csus J, Hafez OI, HagGerTy HS. Neurotrophic factors modulate hair cells and their potassium currents in chick otocyst explants. Eur. J. Neurosci. 11:682-690, 1999.

TANAKA K, SMith CA. Structure of the chicken's inner ear: SEM and TEM study. Am. J. Anat. 153:251-272, 1978.

Tilney LG, SAUnders JC. Actin filaments, stereocilia and hair cells of the bird cochlea I. Length, number, width and distribution of stereocilia of each hair cell are related to position of the hair cell on the cochlea. J. Cell Biol. 96:807-821, 1983.

TiLnEy LG, Tilney MS. Functional organization of the cytoskeleton. Hear. Res. 22:55-77, 1986.

Tilney LG, Tilney MS, SAunders JS, DeRosier DJ. Actin filaments, stereocilia, and hair cells of the bird cochlea III. The development and differentiation of hair cells and stereocilia. Dev. Biol. 116:100$118,1986$.

Tucker T, FetTiplace R. Confocal imaging of calcium microdomains and calcium extrusion in turtle hair cells. Neuron 15:1323$1335,1995$.

Tucker T, Fettiplace R. Monitoring calcium in turtle hair cells with a calcium-activated potassium channel. J. Physiol. 494:613626, 1996.

WANG YZ, Christakos S. Retinoic acid regulates the expression of the calcium binding protein, calbindin-D28k. Mol. Endocrinol. 11:1510-1521, 1995.

WhiteHEAD MC, MOREST DK. The development of innervation patterns in the avian cochlea. Neuroscience 14:255-276, 1985a.

WhiteHEAD MC, MOREST DK. The growth of cochlear fibers and the formation of their synaptic endings in the avian inner ear: 
a study with the electron microscope. Neuroscience 14:277300, 1985b.

Wu YC, FetTiPlace R. A developmental model for generating frequency maps in the reptilian and avian cochleas. Biophys. J. 70:2557-2570, 1996.
Wu YC, TUCKER T, FetTiPLACE R. A theoretical study of calcium microdomains in turtle hair cells. Biophys. J. 71:2256-2275, 1996. ZIDANIC M, FUCHS PA. Synapsin-like immunoreactivity in the chick cochlea: specific labeling of efferent nerve terminals. Aud. Neurosci. 2:347-362, 1996. 